\title{
Effect of Dietary Toasted Leucaena Leucocephala Seed Meal On the Growth and Feed Utilization of Clariid Catfish Clarias gariepinus Fingerlings
}

\author{
*Aliu B.S. and Obuseli, O.I. \\ *Department of Fisheries, University of Benin, Benin-City, Nigeria. \\ Email: bayo.aliu@uniben.eduPhone no: +2348055314843 \\ *Corresponding Author
}

\begin{abstract}
An experiment was designed and carried out to assess the growth performance and feed utilization (weight gain, feed conversion ratio, protein efficiency ratio, specific growth rate, feed intake and survival) of Clarias gariepinus fingerlings fed graded levels of toasted Leucaena leucocephala seed meal based diets with the aim of establishing the best inclusion level of Leucaena seed meal. One hundred and eight (108) fingerlings with an initial mean weight of $2.10 \mathrm{~g}$ were allotted at random to six treatments in triplicate groups with each treatment tank having six fingerlings and were fed with isocaloric and isonitrogenous diets containing $40 \%$ crude protein (CP). The toasted seed meal was used to replace soybean meal in the diets in the following proportions: diets I (0\%), diets II (10\%), diets III (20\%), diets IV $(30 \%)$, diets $V(40 \%)$ and diets VI (50\%). At the end of the feeding trials that lasted for 6 weeks, the mean weight gains of fish, relative weight gain, specific growth rate, feed intake, feed conversion ratio and protein efficiency was highest in treatment I while mean weight gain of fish, relative weight gain, specific growth rate and feed conversion ratio was lowest in treatment $V$. Feed intake was lowest in treatment VI and protein efficiency was lowest in treatment II. Survival among treatments slightly varied significantly but was not as a result of the feed consumed. At the end of the experiment, the recommended inclusion level of Leucaena seed meal was $20 \%$.
\end{abstract}

Keywords: Clariid catfish, Clarias gariepinus, fingerlings, Leucaena Leucocephala, fish diet. 


\section{Introduction}

Worldwide, fish has continued to provide nutritional and health benefits to mankind due to the fact that fish products are low in fats and high in protein, vitamins, minerals and polyunsaturated fatty acids. In developing countries, fish is a highly acceptable food that supplies as much as $40 \%$ of all animal protein (Edgerton and Assarsson, 1998). Aquaculture which is the specialized farming of aquatic organisms particularly fish is one of the fastest growing food producing sectors in the world accounting for approximately $50 \%$ of fisheries products (FAO, 2010). As accounted by Craig and Helfrich (2002), nutrition is critical in fish farming even as it represents $40-50 \%$ of total fish production costs. This further explains that the standard of fish farming and levels of production largely depends on the standard of fish nutrition. Although fish nutrition has advanced dramatically in recent years with the development of new and balanced commercial diets that promote optimal fish growth and health, protein which averages between 18-42\% depending on the fish breed (Craig and Helfrich, 2002) remains the basic requirement in formulated fish feeds for fish growth and production.

\section{Materials and Methods \\ Preparation of Leucaena And Soyabean Meal}

Leucaena seeds were harvested from the L. leococephala shrubs that were found around the Faculty of Agriculture, University of Benin. Matured and dried pods (brown) were collected and placed into plastic containers. The seeds were later sundried at $32^{\circ} \mathrm{C}$ for two days to ensure all seeds were dried uniformly. A pot was placed on fire and heated up with low heat for 2 minutes before the seeds were introduced into the pot. They were stirred continuously for 10-15 minutes or till the seed coat became reddish brown in colour and emitting a sweet aroma. They are then removed and allowed to cool before milling to fine particles. It was there after sieved to remove the skin of the seeds. Fresh soyabean seeds were purchased from Uselu market in Benin City and poured into a preheated pot and toasted in a similar manner as was carried out with the Leucaena seeds and milled.

\section{Preparation of Experimental Diets}

Fishmeal, corn meal, wheat offal and bone meal, multivitamin capsule (vitamin premix) and vitamin E-gel that were used in the production of the feed were purchased from a private company at Murtala Mohammed Way in Benin City. The multivitamin capsule (vitamin premix) and vitamin E-gel were purchased from a pharmaceutical shop and the groundnut oil was obtained from the market in Benin City. Six isonitrogenous and isocaloric diets with a crude protein level of $40 \%$ were formulated. Diets 1, 2, 3, 4, 5 had soybean meal protein substituted with leucaena seed meal at 10\%, 20\%, 30\%, 40\%, 50\% respectively while the control had no leucaena seed meal present in it. The composition of the experimental diets is shown in Table 1. All the ingredients were purchased at the same time and were well ground, mixed. The corn meal was boiled in water to form gel and served as a binder and made into pellets with a pelleting machine available in the Department of Fisheries farm at the University of Benin. The diets were dried in the Departmental smoking kiln at $110^{\circ} \mathrm{C}$ and then stored in air-tight containers throughout the experimental period. 
Table 1: Percentage composition of experimental diets.

\begin{tabular}{|c|c|c|c|c|c|c|}
\hline \multicolumn{7}{|c|}{ TREATMENTS } \\
\hline INGREDIENTS & $\mathbf{I}$ & II & III & IV & $\mathrm{V}$ & VI \\
\hline $\begin{array}{l}\text { Fishmeal(65.5\% } \\
\text { CP) }\end{array}$ & 25.00 & 25.00 & 25.00 & 25.00 & 25.00 & 25.00 \\
\hline $\begin{array}{l}\text { Soybean meal (full } \\
\text { fat) }(38.8 \% \mathrm{CP})\end{array}$ & 54.00 & 44.00 & 34.00 & 24.00 & 14.00 & 4.00 \\
\hline $\begin{array}{l}\text { Leucaena seed } \\
\text { meal }(40 \% \mathrm{CP})\end{array}$ & 0.00 & 10.00 & 20.00 & 30.00 & 40.00 & 50.00 \\
\hline Maize $(9.5 \% \mathrm{CP})$ & 5.00 & 5.00 & 5.00 & 5.00 & 5.00 & 5.00 \\
\hline $\begin{array}{l}\text { Wheat } \\
(12.6 \% \mathrm{CP})\end{array}$ & 3.00 & 3.00 & 3.00 & 3.00 & 3.00 & 3.00 \\
\hline Groundnut oil & 8.36 & 8.36 & 8.36 & 8.36 & 8.36 & 8.36 \\
\hline Bone meal & 0.04 & 0.04 & 0.04 & 0.04 & 0.04 & 0.04 \\
\hline Vitamin premix & 0.60 & 0.60 & 0.60 & 0.60 & 0.60 & 0.60 \\
\hline Vitamin E-gel & 0.04 & 0.04 & 0.04 & 0.04 & 0.04 & 0.04 \\
\hline $\begin{array}{l}\% \quad \text { substitution } \\
\text { Leucaena } \text { seed }\end{array}$ & $0 \%$ & $10 \%$ & $20 \%$ & $30 \%$ & $40 \%$ & $50 \%$ \\
\hline
\end{tabular}

\section{Experimental Fish}

Two hundred (200) Clarias gariepinus fingerings were obtained from a reputable fish farm. They were held in a plastic tank at the Departmental fish farm upon arrival. They were acclimatized for one week in the farm during which they were fed with locally formulated feed (containing fishmeal, soybean cake, wheat offal, palm oil, bone meal, vitamin premix and starch) produced at the Departmental fish farm.

\section{Experimental Units}

Eighteen rectangular (18) plastic tanks measuring $(30 \mathrm{~cm} \times 36 \mathrm{~cm} \times 52 \mathrm{~cm})$ were purchased from the market and labeled with a white tape and marker. Theexperiment was carried out at the Faculty of Agriculture main Laboratory, University of Benin. Each tank was filled with water up to $2 / 3$ of its volume with tap water.

\section{Experimental Procedure}

At the end of the acclimation, 15 fishes were weighed to get the initial weight of fish and a total of 108 fingerlings were transferred in batches of 6 into each of the experimental units that were replicated three times for each treatment. They were fed twice daily to satiation to ensure maximum growth between 8:00am and 9:00am and 3:00pm and 4:00pm. Feeding was monitored for each unit to ensure that fishes were not underfed or overfed. The experimental units were cleaned daily by siphoning with a thin hose to remove unconsumed feed and feacal waste of the fish to reduce pollution of the water. Water in each unit is reduced by half and replaced before fishes are fed so as to provide more dissolved oxygen. Total replacement of water was made during the weekly weighing of fish. All fish per treatment were weighed and counted weekly to determine growth and survival. 


\section{Parameters Monitored}

Data on feed consumed and weight gain were collected weekly for each unit from which the following performance parameters were evaluated.

1) Mean weight gain $(\mathrm{g})$

2) Total feed intake (g)

3) Average daily feed intake (g/day)

4) Total weight gain $(\mathrm{g})=$ final body weight - initial body weight

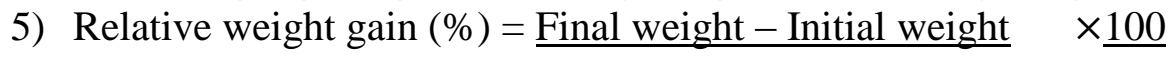
Initial weight

6) Feed conversion ratio $(\mathrm{FCR})=\underline{\text { Weight of feed intake }}$ Wet weight of fish $(\mathrm{g})$

7) Specific growth rate $(\mathrm{SGR})=\underline{\mathrm{Ln} \text { final weight }-\mathrm{Ln} \text { initial weight }} \times \underline{100}$ Time (in days)

8) Percentage weight gain $(\mathrm{PWG})=\underline{\text { Mean weight gain }} \times \underline{100}$ Initial mean weight 1

9) Protein efficiency ratio $=$ Mean weight gain $(\mathrm{g})$ Protein intake $(\mathrm{g})$

10) Survival $(\%)=\underline{\text { Total no of survival } \times 100}$ Total number stocked 1

11) Mean weekly weight gain $=$ Total weight gain $(\mathrm{g})$ Time (days) of experiment

\section{Proximate Analysis of Diets and Fish}

A sample of 15 fishes of the initial stock as well as some survivals from each treatment was sacrificed at the commencement and end of the experiment. Diet samples from the six diets were also collected. They were analyzed using standard methods of the Association of Official Analytical Chemists (AOAC, 1990) for protein, fat, ash and moisture. The moisture content was determined by heating the samples in an oven at a temperature of $105^{\circ} \mathrm{C}$ for 24 hours and recording the weight loss, the crude protein content was estimated by multiplying the nitrogen content by 6.25 , lipid content was determined by ether extraction, the ash was determined by combusting the samples in a muffle furnace at $600^{\circ} \mathrm{C}$ for 5 hours.

\section{Statistical Analysis}

The data obtained from the feeding trials were analysed using the computer software Genstat Version 8.1 (2005). Completely randomized design in a one-way ANOVA was used to calculate the mean. The differences in mean were compared using Duncan's multiple range test.

\section{Results}

The proximate composition of experimental diet (Table 2) shows that moisture was highest in diet VI and lowest in diet V. The crude protein was highest in diet VI (49.20\%) and lowest in diet II $(24.75 \%)$. The crude fat (ether extract) level in the diets were irregular with diet II having the highest at $30.70 \%$ and diet IV and VI been the lowest at $27.00 \%$. The crude fibre level were relatively similar in all the diets with diet II having the highest value at $5.61 \%$ and 
diet V showing the lowest at $4.76 \%$. Ash content was fairly uniform with $9.00 \%$ in diet III making it the highest and $8.00 \%$ in diet IV making it the lowest. N.F.E was highest in diet II which was 15.94 and lowest in diet I which was 0.35 .

Proximate composition of test fish (Table 3) shows that moisture content was highest in fish fed with diet I at 5.31\% and lowest in fish fed with diets IV and VI at 5.00\% crude protein level was irregular been highest in fish fed the test diets with $64.20 \%$ in diet II and lowest in diet 49.00. The trend in fat content shows similar variations with diet VI been the highest at $23.31 \%$ and diet I been the lowest at $21.00 \%$. Ash content of test fish was highest in fish fed with diet I at $10.21 \%$ and lowest in diet IV at $8.45 \%$.

Table 2: Proximate composition (\%) of experimental diets

\begin{tabular}{lcccccc}
\hline & \multicolumn{3}{c}{ TREATMENT } & & & \\
\hline Proximate composition & I & II & III & IV & V & VI \\
\hline Moisture content (\%) & 10.20 & 15.10 & 10.10 & 15.30 & 10.00 & 10.10 \\
Crude protein (\%) & 48.75 & 24.75 & 38.00 & 32.75 & 39.75 & 49.20 \\
Ether extract (\%) & 27.20 & 30.70 & 27.20 & 27.00 & 28.30 & 27.00 \\
Crude fibre (\%) & 5.20 & 5.61 & 5.00 & 5.30 & 4.76 & 5.00 \\
Ash (\%) & 8.30 & 8.50 & 9.00 & 8.20 & 8.10 & 8.00 \\
N.F.E & 0.35 & 15.94 & 10.70 & 11.45 & 9.09 & 0.70 \\
\hline
\end{tabular}

Table 3: Carcass composition (\%) of Clarias gariepinus fingerlings fed varying levels of L. leucocephala seed meal based diets for 42 days.

\begin{tabular}{|c|c|c|c|c|c|c|c|}
\hline & $\begin{array}{l}\text { Initial fish } \\
\text { carcass }\end{array}$ & TSF I & TSF II & TSF III & TSF IV & TSF V & TSF VI \\
\hline Moisture content & 5.21 & 5.31 & 5.12 & 5.22 & 5.00 & 5.13 & 5.00 \\
\hline Ash & 8.43 & 10.21 & 9.23 & 9.52 & 8.45 & 9.13 & 9.42 \\
\hline Fat & 23.21 & 21.00 & 21.31 & 22.34 & 23.00 & 23.21 & 23.31 \\
\hline Crude protein & 61.25 & 52.50 & 64.20 & 49.00 & 57.75 & 52.50 & 54.25 \\
\hline N.F.E & 1.90 & 10.98 & 0.14 & 13.92 & 5.80 & 10.03 & 8.02 \\
\hline
\end{tabular}

\section{TSF $=$ Test fish carcass composition}

Carcass fed with diet II had the highest crude protein value $(64.20 \% \mathrm{CP})$ and carcass fed with diet III had the lowest value $(49.00 \% \mathrm{CP})$. When compared with the initial value $(61.25 \%$ $\mathrm{CP})$, treatments II increased $(64.20 \% \mathrm{CP})$ while treatment IV, VI, I, V and III reduced. Carcass of diet I and V had the same values. Lipid value also varied with treatments been highest in treatment VI and lowest in treatment I. 
Table 4: Growth response and nutrient utilization of $C$. gariepinus fingerling fed Leucaena leucocephala seed meal based diets.

\section{TREATMENT}

\begin{tabular}{lccccccc}
\hline PARAMETER & I & II & III & IV & V & VI & SEM \\
& $\mathbf{0 \%}$ & $\mathbf{1 0 \%}$ & $\mathbf{2 0 \%}$ & $\mathbf{3 0 \%}$ & $\mathbf{4 0 \%}$ & $\mathbf{5 0 \%}$ & \\
Mean weight gain (g) & $1.07^{\mathrm{a}}$ & $0.45^{\mathrm{b}}$ & $0.47^{\mathrm{b}}$ & $0.37^{\mathrm{b}}$ & $0.25^{\mathrm{b}}$ & $0.38^{\mathrm{b}}$ & 0.27 \\
Relative weight gain (\%) & 30.10 & 14.40 & 22.70 & 13.70 & 10.10 & $12.40^{\mathrm{NS}}$ & 9.57 \\
Specific growth rate (\%) & 3.49 & 2.75 & 2.40 & 1.51 & 1.27 & $3.48^{\mathrm{NS}}$ & 1.84 \\
Feed intake (g) & $5.40^{\mathrm{a}}$ & $3.91^{\mathrm{c}}$ & $4.48^{\mathrm{b}}$ & $3.66^{\mathrm{cd}}$ & $3.43^{\mathrm{d}}$ & $3.42^{\mathrm{d}}$ & 0.20 \\
Feed conversion ratio & 2.54 & 2.83 & 3.09 & 3.50 & 3.45 & $3.28^{\mathrm{NS}}$ & 2.26 \\
Protein efficiency ratio (\%) & $1.40^{\mathrm{a}}$ & $0.63^{\mathrm{b}}$ & $0.90^{\mathrm{ab}}$ & $0.70^{\mathrm{ab}}$ & $0.68^{\mathrm{ab}}$ & $0.79^{\mathrm{ab}}$ & 0.33 \\
Survival & $70.40^{\mathrm{ab}}$ & $74.10^{\mathrm{a}}$ & $67.60^{\mathrm{abc}}$ & $60.20^{\mathrm{c}}$ & $73.10^{\mathrm{ab}}$ & $63.90^{\mathrm{ab}}$ & 4.48 \\
\hline
\end{tabular}

Figures in each row with the same superscript are not significantly different $(P>0.05)$ $\mathrm{SEM}=$ standard error of mean $\quad$ NS = means no significant difference

At all levels of substitution, the mean weight gain was slightly different. The highest mean weight was recorded in treatment I (1.07) that was fed with diet containing $0 \%$ leucaena seed meal. This treatment was significantly different $(\mathrm{P}>0.05)$ from the rest treatments and moving from treatment II to treatment IV there was no significant difference in weight gain as it was irregular with increasing inclusion levels with treatment $\mathrm{V}(0.25)$ having the lowest weight gain. Relative weight gain showed no significant difference $(\mathrm{P}>0.05)$ between all treatments as weight gain was similar with treatment I $(30.10 \%)$ been the highest and treatment V $(10.10 \%)$ been the lowest. There was no significant difference $(\mathrm{P}>0.05)$ in specific growth rate implying that it was similar with all treatments. Treatment I (3.49\%) had the highest growth rate with specific growth rate dropping steadily from treatment II to $\mathrm{V}$ $(2.75 \%, 2.40 \%, 1.51 \%$ and $1.27 \%)$ and then rising again at treatment VI (3.48\%). Feed intake was significantly different $(\mathrm{P}>0.05)$ meaning that feed was consumed at different levels of intensification within each treatment. Treatment I had the highest feed intake of $5.40 \mathrm{~g}$. Feed intake reduced in treatment II (3.91g), increased again in treatment III (4.48g) and dropped steadily from treatment IV to VI been the lowest $(3.66 \mathrm{~g}, 3.43 \mathrm{~g}$ and $3.42 \mathrm{~g})$. This indicates that feed consumed decreased as level of inclusion of leucaena seed meal increased from treatment III. There was no significant difference $(\mathrm{P}>0.05)$ in the feed conversion ratio of all the treatments indicating that food was converted to flesh at similar rate. FCR was highest in treatment I (2.52) and lowest in treatment VI (3.50). The FCR was uneven with increasing inclusion levels. Protein efficiency ratio was slightly significantly different $(P>0.05)$ for the various treatments. It was highest in treatment I (1.40\%) and lowest in treatment II $(0.63 \%)$. 
Survival was slightly significantly different $(\mathrm{P}>0.05)$ in each treatment with treatment II (74.10) having the highest survival rate followed by treatment V (73.10), treatment I (70.40), treatment III (67.60), treatment VI (63.90) and treatment IV having the lowest survival rate (60.20). The values gotten indicate that inclusion levels did not affect the survival of the fish.

\section{Discussion}

The growth rate was generally slow, however it was highest in treatment I (30.10\%) and decreased variably as the inclusion level of leucaena seed meal (LSM) increased (treatment III had $22.70 \%$, treatment II had $14.40 \%$, treatment IV had $13.70 \%$, treatment VI had $12.30 \%$ and treatment $\mathrm{V}$ had $10.10 \%$ ). The seeming slow growth rate that was highest in leucaena replaced diets may have been as a result of the presence of heat resistance anti nutrients (Alegbeleye et al., 2001) which might not have been totally removed with toasting and the non-inclusion of essential amino acid methionine which is known to be limiting in both test ingredients (soybean and leucaena) (FAO, 1983). This observed pattern could also probably be a result of persistent consumption of leucaena meals which could retard animal growth rate as reported by Tangendijajaet al., (1990) who recorded progressive depressed growth rate in rabbit fed increasing graded levels of leucaena leaf meal based-diet. Nutrient utilization (feed conversion) of fish decreased as level of LSM inclusion increases in the diets.

The poor nutrient utilization may not be hinged on the fibre content of the test diets as this was generally less than $10 \%$ as recommended by Aladetohun (2008), who stated that the main factor in the digestibility of feed is the fibre content. In this observation, this may be as a result of the presence of toxins or nutrient imbalance that is associated with plant protein source (De Silva and Gunasekara, 1989). The variation in growth and nutrient utilization by fish (with some having lower, higher and then lower growth and nutrient utilization) with increasing inclusion levels is not in agreement with Sotolu and Faturoti (2009), who reported that the growth and nutrient utilization of diets by fish decreased as level of LSM inclusion increases in the diets.

Heat treatment is known to detoxify anti nutrients but retarded growth and nutrients utilization recorded in this study was in line with the findings of Sotolu and Faturoti (2008), who reported that heat treated leucaena seeds gave lower performance than leucaena soaked in water and sundried. Heating of the seeds could have also resulted in the destruction of the amino acid bonds thereby reducing the protein quality of the feed ingredients. This was supported by Osuigwe et al., (2005) that heating destroys and reduces nitrogenous compounds in legume seeds. From observation, feed intake was satisfactory in the first week of the experiment but decreased variably afterwards with increasing inclusion levels of leucaena seed meal. This issimilar to the findings of Ahmed and Abdelati, (2009) and Atawodi et al., (2008) who reported that Leucaena leucocephala supplementation progressively decreased appetite in laying hens.

Protein efficiency ratio (PER) was highest in fish fed with 0\% LSM meal but it was similar statistically to values of 20\%,30\%, 40\% and 50\% LSM inclusion. This is not in conformity with what was stated by Sotolu and Faturoti (2009), who reported that similarity in the PER of Clarias gariepinus has a direct link with feed intake. All diets produced different values of fish carcass protein and lipid than initial values with marginal difference among them 
indicating different utilization levels of the diets. These relatively high value of protein can be crude protein could be viewed alongside the work of Alegbeleye et al.,(2001) who reported that effective utilization of bambara groundnut at varying rates was responsible for variations in Heteroclarias carcass protein and lipid.

The non-detection of crude fiber in the fish carcass composition was the same in all treatments and this had been said to be associated with effective utilization of diets according to Sotolu and Faturoti (2008).Based on this study, it has been observed that fish with lower LSM inclusion levels had better health status than those of higher LSM inclusions based on earlier submissions of Svobodova et al., (1991), Alegbeleye (2005), Ochang et al., (2007) and Sotolu and Faturoti (2009).

\section{Conclusions}

There was a general low performance of diets with $0 \%$ - 50\% inclusion levels of LSM. Diet I with $0 \%$ inclusion of LSM was the best. Diet III with $20 \%$ inclusion level of LSM performed best among diets that had LSM present in it. The low performance of the diets with $10 \%$ $50 \%$ inclusion levels of LSM may have been as a result of partial detoxification of the anti nutrient (mimosine) present in the leucaena seed in addition adverse rearing and environmental conditions in which the experimental was conducted. From the study carried out, the recommended levels of LSM are $0 \%$ and $20 \%$ since they performed better than the other inclusion levels. 


\section{References}

Ahmed, M. E. and Abdelati, K. A. (2009). Chemical composition and amino acids profile of Leucaenaleucocephalaseeds. International Journal of Poultry Science 8(10): 966970.

Aladetohun, N. F. (2008). The utilization of sorghum husk in the nutrition of tilapia (Oreochromisniloticus). NIOMR technical publication. pp 33-46.

Alegbeleye W. A. O. (2005). Growth an d haematological profiles of Oreochromisniloticus( Trewasvas, 1983) fingerlings fed differently processed Cottonseed (Gossypnium hirsute 1783) Meal. Ph. D Thesis, University of Ibadan, Ibadan. Nigeria. 213pp.

Alegbeleye W. O.; A. O. Oresegun and O. Omitoyin. (2001). Use of bambara groundnut (Vignasubterranean) meal in the diets of Heteroclarias fingerlings. Moor Journal of Agricultural Research. (2): 54-59.

Atawodi , S. E., Mari, D., Atawodi, J. C. and Yahaya, Y. (2008). Assessment of Leucaenaleucocephalaleaves as feed supplement in laying hens. African Journal of Biotechnology 7 (3). Pp 317321.

Craig, S. and Helfrich, L. A. (2009). Understanding Fish Nutrition, Feeds and Feeding. In: Virginia Cooperative Extension, Virginia Polytechnic Institute and State University. Pp 420-256.

Craig, S., and Helfrich, L. A. (2002). Understanding Fish Nutrition, Feeds, and Feeding. Virginia Polytechnic Institute and State University. Publication 420-256.

De Silva, S. S. and Gunasekara, R. M. (1989). Effects of dietary protein level and amount of plant ingredients (Phaseolus aureus) incorporated into the diets on consumption, growth performance and carcass composition in Oreochromisniloticus fry. (80) 121133.

Edgerton, D. and Assarsson , B. (1998). The Econometrics of Demand Systems: With Applications to Food Demand in Nordic Countries. Kluwer Academic Press, Boston. Pp 34-39.

FAO, (1983). Fish feeds and feeding in developing countries. An interim reports on the ADCP Feed development programme. ADCP/REP/83/18.

FAO, (2010). The state of the world fisheries and aquaculture. FAO Fisheries and Aquaculture Department. Food and Agriculture Organization of the United Nation. Rome, 218pp.

Ochang, S. N., Fagbenro, O. A. and Adebayo, O. T. (2007). Growth performance and body composition, haematology and product quality of the African catfish (Clariasgariepinus) fed diets with palm oil. Palestine Journal of Nutrition 6 (5): 452459.

Osuigwe, D. I., Obiekezie, A. I. and Onuoha, G. C. (2005). Some heamatological changes in hybrid catfish ( $H$. longifilis $x$ C. gariepinus)fed different dietary levels of raw and boiled jackbean (Canavaliaensiformis) seed meal. African Journal of Biotechnology. 4(9): 1017-1021.

Sotolu A.O. \&Faturoti E.O. (2009), Growth performance haemotology of Clariasgariepinus (Burchell, 1822) fed varying inclusions of leucaenaleucocephalaseed meal baseddiets. Revista UDO Agricola 9 (4): 979-985.

Sotolu, A. O. and Faturoti, E. O. (2008). Digestibility and nutritional values of differently processed Leucaenaleucocephalaseed meals in the diet of African catfish (Clariasgariepinus). Middle East Journal of Scientific Research 3 (4): 190-199. 
Svobodova, Z., Fravda, D. and Palakova, J. (1991) Unified methos of haemotological examination of fish. Research institute of fish culture and hydrobiology, Vodnany, Czechoslovakia. $331 \mathrm{pp}$.

Tangendijaja, B., Raharjo Y. C. and Lowry, J. B. (1990). Leucaena leaf meal in the diet of growing rabbits: Evaluation and effect of a low mimosine treatment. Animal Feed Science and Technology. (29): 63-72. 